\title{
Przejawy europeizacji w prawie rolnym
}

\section{Uwagi wprowadzające}

Problematyka europeizacji polskiego prawa jest współcześnie jednym z zagadnień naukowych podejmowanych w wielu dyscyplinach prawniczych. ${ }^{1}$ Zjawisko to dotyczy również prawa rolnego. Proces harmonizacji z prawem UE wywarł wpływ zarówno na zagadnienia ogólne prawa rolnego, m.in. zakres i źródła prawa rolnego, jak i na kwestie szczegółowe, o dużym praktycznym znaczeniu (np. standaryzacja, normy fitosanitarne), a obecnie zwłaszcza na instrumenty prawne wsparcia rozwoju obszarów wiejskich.

Przedmiotem opracowania jest próba oceny wpływu prawa wspólnotowego na prawo rolne poprzez analizę kilku instrumentów wprowadzonych po akcesji naszego kraju do UE, lecz także dokonanie szerszego spojrzenia na przemiany zachodzące w tej dziedzinie pod wpływem rozwiązań wspólnotowych. Rozważenia wymaga również kwestia czynników oddziaływujących na zakres zjawiska europeizacji w prawie rolnym, jak też określenie roli państw członkowskich w kształtowaniu przyjmowanych rozwiązań prawnych.

Z uwagi na ramy pracy nie jest możliwe całościowe omówienie podjętej problematyki. Dlatego odnotowanych zostało kilka rozwiązań, ukształtowanych pod wpływem prawa UE lub stanowiących przejaw tego prawa: instrumenty ochrony środowiska w rolnictwie, instrumenty wsparcia dla obszarów o niekorzystnych warunkach gospodarowania i instrumenty prawne wsparcia dochodowości, w postaci płatności bezpośrednich do gruntów rolnych. Uzasadnieniem wyboru wskazanych zagadnień jest ukazanie się nowych priorytetów, artykułujących założenia Wspólnotowej Polityki Rolnej (WPR) i ich wpływ na kształt przyjętych rozwiązań prawnych. Ochrona i poprawa stanu środowiska w rolnictwie, uznana za integralną część tej polityki, obok funkcji ekologicznej, pełni podwójną funkcję społeczną. Z jed-

Świadczą o tym publikacje przedstawicieli różnych dziedzin prawa, np. Europeizacja prawa krajowego, Wpływ integracji na klasyczne dziedziny prawa krajowego, red. C. Mik, Toruń 1999 czy Europeizacja polskiego prawa pracy, red. W. Sanetra, Warszawa 2004, jak również Europeizacja polskiego prawa administracyjnego, red. Z. Janku, Z. Leoński, M. Szewczyk, M. Waligórski, K. Wojtczak, Warszawa 2005. 
nej strony redukcja środków chemicznych, wykorzystanie metod rolnictwa ekologicznego, ochrona krajobrazu wiejskiego są działaniami podejmowanymi w interesie publicznym, z drugiej - służą też rozwojowi obszarów wiejskich. Ponadto instrumenty stymulujące do mniej intensywnych metod produkcji rolnej przyczyniają się do ograniczenia jej poziomu i stają się jednym z elementów procesu dostosowania niektórych sektorów do wymagań rynku. Z uwagi na rozległość problematyki ochrony środowiska w rolnictwie i ramy opracowania odnotowane zostały rozwiązania prawne dotyczące stosowania środków ochrony roślin. Celowość wskazania instrumentów wsparcia dla terenów o trudnych warunkach gospodarowania w rolnictwie jest podyktowana wprowadzeniem do ustawodawstwa wymogu różnicowania instrumentów prawnych w zależności od warunków naturalnych poszczególnych regionów rolniczych, co jest uzasadnione względami społecznymi, gdyż przyczynia się do utrzymania właściwego poziomu dochodów rolników i przeciwdziała depopulacji obszarów wiejskich. Rolnicze użytkowanie tych terenów gwarantuje ochronę środowiska, utrzymanie walorów krajobrazu, a co za tym idzie zachowanie ich potencjału społeczno-gospodarczego. Natomiast środek finansowo-prawny w postaci płatności bezpośrednich do gruntów rolnych stanowi wyraźnie wyraz powiązania instrumentów wspólnotowej polityki rynkowej z ochroną środowiska.

Analiza rozwiązań normatywnych we wskazanym zakresie zostanie poprzedzona rozważaniami wprowadzającymi, służącymi ukazaniu czynników wpływających na wymiar tego zjawiska w prawie rolnym.

\section{Czynniki europeizacji prawa rolnego}

Europeizacja prawa² stanowi postać obserwowanego od dawna zjawiska recepcji w prawie, czyli wykorzystania rozwiązań prawnych przyjętych w innych krajach, a stanowiących uznany dorobek światowej myśli prawniczej ${ }^{3}$. Współcześnie termin jest używany przeważnie na oznaczenie unifikacji i integracji prawa w ramach UE, ale w szerszym znaczeniu określenie to może być odnoszone do przyjmowania fundamentalnych idei, odnotowywanych od kilkudziesięciu lat w wielu systemach prawnych państw europejskich. ${ }^{4} \mathrm{~W}$ odniesieniu do prawa rolnego, termin ten

Zjawisko to nazywane jest też w doktrynie „uwspólnotowieniem prawa”, por.: R. Budzinowski, Prawo rolne między historią a przeszłościa, (w:) Zagadnienia prawa cywilnego, samorządowego i rolnego, Księga pamiątkowa prof. W. Pańko, Katowice 1993, s. 146, 154 oraz E. Tomkiewicz, Limitowanie produkcji w ustawodawstwie rolnym Wspólnoty Europejskiej, Warszawa 2000, s. 59.

$3 \quad$ M. Wyrzykowski, Recepcja w prawie publicznym - tendencje rozwojowe konstytucjonalizmu w Europie Środkowej i Wschodniej, PiP 1992, z. 1, s. 23 i n.

4 Rozważania dotyczące różnego zakresu omawianego terminu prowadzą M. Zirk-Sadowski, Filozoficzno-teoretyczne aspekty harmonizacji polskiego porządku prawnego z europejskim prawem wspólnotowym, (w:) System prawa RP w procesie europeizacji, red. M. Matey-Tyrowicz, Warszawa 2002, s. 12 czy Z. Leoński, (w:) Z. Janku, Z. Leoński, M. Szewczyk, M. Waligórski, K. Wojtczak (red.), op. cit., s. 13. W najszerszym ujęciu odnotowuje się nawet „stworzenia europejskiej przestrzeni prawa”, czy „europejskiej kultury prawnej”. Por. zwłaszcza K. Lankosz, Europejska przestrzeń prawna u progu XXI wieku, (w:) Współczesne wyzwania europejskiej przestrzeni prawnej, księga pamiątkowa prof. E. Piontka, red. A. Łazowski, R. Ostrowski, Kraków 2005, s. 27-33 oraz R. To- 
może oznaczać wymóg implementacji obowiązującej regulacji prawnej UE, artykułującej założenia WPR. Podkreślenia wymaga uwidocznienie się, na skutek wpływu rozwiązań europejskich, pewnych podstawowych koncepcji, charakterystycznych współcześnie dla tej dziedziny prawa, takich jak m.in. zapewnienie bezpieczeństwa jakości produktów żywnościowych czy ochrona środowiska w rolnictwie.

Aktualnie jednym $\mathrm{z}$ determinantów procesu zmian w systemie prawa polskiego pozostaje niedawno uzyskane członkostwo w UE. Jednakże uwzględniając zróżnicowany w poszczególnych dziedzinach stopień unifikacji prawa ${ }^{5}$, można zauważyć, że na zakres europeizacji w prawie rolnym może mieć wpływ kilka czynników: historyczny, obrotu międzynarodowego, wspólnego europejskiego rynku i ekologiczny.

Pierwszy z tych czynników można określić jako historyczny. Polskie ustawodawstwo rolne od początku wyodrębnienia się tej dyscypliny pozostawało pod wpływem rozwiązań funkcjonujących w państwach Europy Zachodniej6. W tym okresie ustawodawca często sięgał do zachodnich tradycji kulturowych, stąd też znamienne było zjawisko przenoszenia, dostosowywanych następnie do warunków krajowych, europejskich wzorów instytucji prawnych ${ }^{7}$. Zjawisko to występuje także współcześnie zarówno w polskim prawie rolnym, jak i w pozostałych państwach członkowskich $\mathrm{UE}^{8}$. Trzeba także podkreślić, że również prawo europejskie sięga do tradycji kulturowych wykształconych na zachodzie Europy. W doktrynie prawa wyrażono pogląd, że unifikacja prawa w ramach UE nie zawsze oznacza potrzebę budowania zupełnie nowego systemu prawnego, lecz jest także nawiązywaniem do wcześniejszych rozwiązań przyjmowanych w państwach członkowskich, z uwzględnieniem aktualnych potrzeb i unijnych tendencji rozwojowych ${ }^{9}$. To trafne spostrzeżenie znajduje potwierdzenie we wspólnotowym prawie rolnym ${ }^{10}$.

karczyk, Problemy harmonizacji polskiej kultury prawnej z kulturą prawną Unii Europejskiej, „Studia Europejskie” 2004, z. 3, s. 69.

Co wskazywał już art. 69 Układu Europejskiego, Dz.U. 1994 r., Nr 11, poz. 38, (dalej cyt. jako: „Układ”).

Szerszego omówienia w tym zakresie dokonał A. Lichorowicz, Szczególne zasady dziedziczenia gospodarstw rolnych w ustawodawstwie krajów zachodnioeuropejskich, Zeszyty Naukowe UJ 1992, Prace Prawnicze, z. 144, s. 160-171 oraz Podstawowe rozwiązania w zakresie obrotu gruntami rolnymi w ustawodawstwie krajów Europy Zachodniej, „Studia Prawnicze” 1991, z. 3, s. 87 i n. Jak wskazuje Z. Leoński, op. cit., s. 13.

8 Przykładem unifikacji rozwiązań prawnych w sferze organizacyjnej państwa są agencje, realizujące zadania w dziedzinie rolnictwa, wzorowane na istniejących we Francji odpowiednikach. Rozwiązania francuskiego systemu prawa stały się inspiracja dla polskiej regulacji w zakresie obrotu nieruchomościami rolnymi, a niedawno postulowano przyjęcie rozwiązań romańskiego modelu dziedziczenia gospodarstw rolnych, zob. A. Lichorowicz, Konstytucyjne podstawy ustroju rolnego RP (w świetle art. 23 Konstytucji), „Studia luridica Agraria” 2000, t. 1, s. 43. Autor wskazywał na przykłady recepcji w ustawodawstwie włoskim, portugalskim czy hiszpańskim, Tenże, Stan i perspektywy rozwoju Wspólnej Polityki Rolnej oraz ich wpływ na charakter i podstawowe kierunki ewolucji norm polskiego prawa rolnego w przededniu wstapienia Polski do Unii Europejskiej, „Studia Prawno-Europejskie", 2002, t. 6, s. 169. chodniej, Białystok 2000, s. 18. 
Drugi czynnik wpływający na zakres europeizacji prawa rolnego można określić jako międzynarodowy. Prawo rolne jest dziedziną prawa związaną z międzynarodowym obrotem handlowym produktami rolnymi. Ujednolicenie polskich norm prawnych z wymogami rynku europejskiego, a szerzej jeszcze światowego ${ }^{11}$, stało się warunkiem uczestnictwa w tym obrocie. Nieodzowność unifikacji prawa w tym zakresie podyktowana była zarówno przesłankami politycznymi, jak i ekonomicznymi $^{12}$. Dlatego też art. 69 Układu, wskazujący dziedziny priorytetowe poddane harmonizacji, stanowił podstawę do zbliżenia polskiego ustawodawstwa rolnego do europejskich standardów zapewniających bezpieczeństwo produktów rolnych, jak również przepisów z zakresu ochrony środowiska, co miało ułatwić swobodny obrót towarów i zwiększyć szanse eksportowe polskich produktów rolnych na rynkach europejskich. ${ }^{13}$

Trzecim czynnikiem, mającym zasadniczy wpływ na zasięg europeizacji prawa rolnego, jest włączenie rolnictwa w ramy wspólnego rynku, poddanie sektora rolnego wspólnej dla wszystkich krajów członkowskich polityce rolnej. Stworzenie jednolitego rynku i ustanowienie szeregu instrumentów ekonomicznego oddziaływania wymagało zintegrowanego zarządzania oraz jednolitych uregulowań prawnych na szczeblu Wspólnoty ${ }^{14}$. Współcześnie, wspólnotowa regulacja prawna w tym zakresie służyć ma również wspieraniu europejskiego modelu rolnictwa. Model ten zakłada rolnictwo zrównoważone, pełniące obok społecznie doniosłej funkcji produkcyjnej, także inne pozagospodarcze funkcje - socjalną i ekologiczną. Z jednej strony zapewnić ma osiągnięcie efektywności prowadzonej produkcji, odpowiedni poziom dochodu producentów rolnych oraz rozwój obszarów wiejskich we wszystkich regionach Wspólnoty, a z drugiej strony - bezpieczeństwo żywności o wysokiej jakości, ochronę środowiska, krajobrazu. Ponadto obecnie instrumenty realizujące założenia WPR są regionalnie zróżnicowane, przez co pozwalają na wypełnianie postulatu europejskiej kohezji. Wykonanie tych modelowych założeń wymaga zunifikowanych form oddziaływania, co wpływa na wymiar zjawiska europeizacji prawa rolnego.

Podobnie czynnik ekologiczny, na przestrzeni ostatnich lat, wpłynął znacząco na poziom ujednolicenia unormowań prawnych w UE. Prawo rolne jest współcześ-

11 Przykładowo Polska ratyfikowała konwencję z 1935 r. o zwalczaniu zaraźliwych chorób zwierzęcych (Dz.U. z 1939 r. Nr 26, poz. 172), czy konwencję Rady Europy z 1976 r. o ochronie zwierząt hodowlanych i gospodarskich, ETS 87, (Dz.U. z 2008 r. Nr 104, poz. 665).

12 Szerzej J. Niemczyk, Czy Europa zachowa model swojego rolnictwa?, „Wspólnoty Europejskie” 2002, z. 12, s. 56 oraz Okresowy Raport 2002 dotyczący przygotowań Polski do członkostwa w UE, opracowany przez Komisję Europejska, „Monitor Integracji Europejskiej” 2002, nr 7 (wyd. specj.), s. 68-69.

13 Postulowali to od początku lat dziewięćdziesiątych przedstawiciele doktryny prawa rolnego, por. m.in.: A. Lichorowicz, Stowarzyszenie Polski z EWG a polskie ustawodawstwo rolne, PiP 1992, z. 9, s. 50-51 i 57; A. Stelmachowski, Problemy harmonizacji prawa w związku z integracją polskiego rolnictwa z Unią Europejską (koreferat), (w:) Polskie prawo rolne u progu Unii Europejskiej, red. S. Prutis, Białystok 1998, s. 61-62.

14 Szerzej A. Jurcewicz, (w:) A. Jurcewicz, B. Kozłowska, E. Tomkiewicz, Wspólna polityka rolna. Zagadnienia prawne, Warszawa 2004, s. 47. 
nie ściśle zintegrowane $\mathrm{z}$ ochroną środowiska. W literaturze przedmiotu już w latach osiemdziesiątych obserwowaną tendencję określano jako ,ekologizację prawa rolnego" 15 . Trzeba też podkreślić, że wzgląd na konieczność zachowania środowiska naturalnego doprowadził na płaszczyźnie międzynarodowej do zawarcia szeregu umów i konwencji, w tym także konwencji Rady Europy, których stroną stały się zarówno UE, jak i Polska ${ }^{16}$. Wiele aktów dotyczyło pośrednio także rolnictwa i spraw objętych WPR, a wprowadzenie ich do systemu prawa przez podmioty prawa międzynarodowego prowadziło do unifikacji rozwiązań prawnych nie tylko w skali europejskiej, lecz także szerzej, w wymiarze światowym.

Prowadzone rozważania służyły ukazaniu czynników wpływających na zakres unifikacji tej dziedziny prawa. Szerszego odnotowania wymagają wybrane instrumenty służące ochronie środowiska w rolnictwie i instrumenty wsparcia dla terenów o utrudnionych warunkach gospodarowania, stanowiące przejaw regionalizacji oddziaływania.

\section{Instrumenty ochrony środowiska w ustawodawstwie rolnym UE}

Wspólnota Europejska po początkowym désintéresment zagadnieniami ochrony środowiska, obok działań na rzecz rozwoju gospodarczego zjednoczonej Europy, podjęła się opracowania wspólnej polityki na rzecz poprawy stanu środowiska. Prawnym wyrazem tych założeń stały się normatywne postanowienia Traktatu Rzymskiego $^{17}$, a zwłaszcza dodany w 1986 r. art. 130r ust. 2, wprowadzający wymóg ujęcia zasad ochrony środowiska w definicjach innych polityk i stosowania tych zasad przy wdrażaniu ich założeń. Umieszczenie w 1997 r. treści tego postanowienia w art. 6 TWE, wśród zasad ogólnych Traktatu, jak również włączenie działań na rzecz zapewnienia wysokiego poziomu ochrony i poprawy jakości środowiska naturalnego do zadań Wspólnoty, określonych w art. 2 TWE ${ }^{18}$, spowodowało wyraźne przesunięcie akcentu ustawodawcy europejskiego, wzmocnienie znaczenia tej problematyki oraz rozszerzenie zakresu stosowania tej reguły na wszystkie wspólne polityki UE. Ostatnio ranga tej zasady, po raz kolejny, została podkreślona poprzez umieszczenie jej postanowień w treści art. 37 Karty Praw Podstawowych $\mathrm{UE}^{19}$.

15 Zob. A. Pankau, Rolnictwo a środowisko, Ekologizacja prawa rolnego, „Prawo Rolne” t. I, Piła 2006, s. 24, autorka przywołuje poglądy wyrażane w latach osiemdziesiątych we włoskiej i niemieckiej doktrynie prawa. Można w tym miejscu wymienić m.in. konwencję z 1992 r. o różnorodności biologicznej (Dz.U. z 2002, Nr 184, poz. 1532) czy konwencję z 1998 r. dotyczącą obrotu niebezpiecznymi substancjami chemicznymi i pestycydami (przyjęta decyzją Rady WE nr 106/2003, O.J. L 63, p. 27). Na marginesie można też wskazać, że Polska już w okresie międzywojennym ratyfikowała konwencję międzynarodową z 1902 r. o ochronie ptaków pożytecznych dla rolnictwa (Dz.U. z 1932, Nr 67, poz. 625). Traktat Rzymski z 25 marca 1957 r., O.J. 2004, 90, p. 864/2 ze zm., (dalej cyt. jako: „TWE”).

Przepisy te zmienione zostały na mocy art. 2 ust. 2 i 4 Traktatu z Amsterdamu z 1997 r., O.J. C 340, p.1. Karta Praw Podstawowych Unii Europejskiej, podpisana w Strasburgu 12 grudnia 2007 r., O.J. C 303, p. 1. 
Norma zawarta $\mathrm{w}$ art. 6 TWE stanowi dyrektywę interpretacyjną, zapewniającą uwzględnianie wymogów ochrony środowiska we wszystkich dziedzinach działalności Wspólnoty poddanych integracji, wprowadzoną w szczególności w celu zrównoważonego rozwoju. W zakresie WPR oznacza to, że wymagania ochrony środowiska muszą być zintegrowane $\mathrm{z}$ instrumentami prawnymi realizującymi założenia polityki rolnej. Powstaje jednakże wątpliwość, czy zasada ta statuuje jedynie wymóg „wzięcia pod uwagę" względów środowiskowych, czy też obowiązek ten idzie dalej, w kierunku nakazu wyważania w każdym przypadku interesów gospodarczych i ekologicznych, a zwłaszcza czy stanowi dyrektywę umożliwiającą rozstrzygnięcie kwestii konfliktu tych interesów. W literaturze przedmiotu prezentowane są różne stanowiska. $Z$ jednej strony podkreśla się, że transpozycja tego postanowienia do części I TWE „Zasady” spowodowała uznanie środowiska swoistą wartością, a jego ochronę ,zasadą zasad”, której muszą być podporządkowane wszystkie wspólne polityki. ${ }^{20} \mathrm{Z}$ drugiej strony spotykamy pogląd, że interesy ekonomiczne, społeczne i ekologiczne należy traktować jako równorzędne, a przepis ten nie daje podstaw do przyznania bezwzględnego pierwszeństwa ochronie środowiska. ${ }^{21}$

Ustosunkowując się do wskazanych poglądów, należy - jak sądzę - wyrazić we wskazanej kwestii odmienne zapatrywanie. Trzeba bowiem zaznaczyć, że przy interpretacji omawianego przepisu kluczowe znaczenie należy przypisać wskazaniu ustawodawcy europejskiego, iż celem ujęcia wymogów środowiskowych w politykach i działaniach Wspólnoty jest zrównoważony rozwój, a więc taki rozwój społeczny i gospodarczy, który nie jest dokonywany za wszelką cenę, kosztem wartości środowiska. Sama idea zasady zrównoważonego rozwoju zakłada wyważanie spornych interesów i mimo braku generalnego prymatu na rzecz ochrony środowiska, w poszczególnych przypadkach dyspozycja art. 6 TWE wprowadza, jak należy sądzić, konieczność uwzględnienia wszystkich możliwości wariantowych rozwiązań i wyboru środka najmniej uciążliwego dla środowiska. Ponadto przyjęcie mniej korzystnego ekologicznie rozwiązania pociąga za sobą obowiązek szczegółowego uzasadnienia podjętej decyzji. Trzeba także zauważyć, że reguła ustanowiona we wskazanym przepisie nie może być interpretowana w oderwaniu od pozostałych wspólnotowych zasad ochrony środowiska, m.in. zasady zapewnienia wysokiego poziomu ochrony środowiska czy zasady przezorności.

Konieczność uwzględniania wymogów środowiskowych w regulacjach prawnych realizujących założenia WPR została podkreślona już kilkakrotnie w orzecz-

G. Biovora, Rolnictwo i środowisko w politykach Unii Europejskiej, „Przegląd Prawa Rolnego” 2007, t. 2, s. 47. A. Wasilewski, Prawna problematyka ochrony środowiska w związku z przystapieniem Polski do Unii Europejskiej. Kwestia granic związania Państwa Członkowskiego prawem WE, „Kwartalnik Prawa Publicznego” 2004, z. 2, s. 190. Taką też linię interpretacyjną prezentował ETS w kilku orzeczeniach wydanych na podstawie art. 130r TWE, m.in. wyrok z 7 listopada 1991 r., C 17/90 Pinaud Wieger, ECR I-5253, w którym sąd w zakresie polityki transportowej nakazywał uwzględnianie problemów ekonomicznych, socjalnych i ekologicznych. 
nictwie Sądu Pierwszej Instancji WE (SPI), m.in. w wyrokach z 2003 r. ${ }^{22}$ i 2007 r. ${ }^{23}$ SPI rozpatrując zarzuty dotyczące włączenia w przepisach wspólnotowych postanowień umożliwiających stosowanie w rolnictwie substancji, mogących negatywnie oddziaływać na zdrowie ludzi, bezpieczeństwo żywności i środowisko, odwołał się do zasady przezorności, ustanowionej w art. 174 ust 2 TWE w celu unikania chociażby potencjalnego zagrożenia środowiska. Zgodnie z jej treścią, w przypadkach podjęcia uzasadnionych podejrzeń dotyczących prawdopodobnych zagrożeń dla środowiska, zdrowia ludzi, organy władzy publicznej powinny podjąć czynności zapobiegawcze, nawet mimo braku jednoznacznych dowodów naukowych w tym zakresie. Nie oznacza to jednak, jak zaznaczył SPI w wyroku z 2002 r. ${ }^{24}$ i 2007 r., obowiązku przyjmowania przez instytucje wspólnotowe założenia zerowej tolerancji, uwzględniania zagrożeń czysto teoretycznych, opartych na niczym niepopartych hipotezach.

SPI we wskazanym wyroku z 2007 r. podkreślił ponadto, iż wybór zastosowanego rozwiązania prawnego przez organy Wspólnot musi zostać podporządkowany regule, a ochrona zdrowia, bezpieczeństwa i środowiska ma przeważać nad ekonomicznymi interesami. Takie stanowisko sądu przemawia, moim zdaniem, za uznaniem szerszej interpretacji, iż gdy jest to niezbędne do skutecznej realizacji zamierzonych celów środowiskowych, zasada ustanowiona w art. 6 TWE, a dookreślona w art. 174 TWE, daje podstawy do obowiązku ochrony wartości środowiska.

W odniesieniu do polityki rolnej szersza wykładnia tej zasady znajduje również uzasadnienie w ustawodawstwie wtórnym. Przejawem uwzględniania wymogów środowiskowych były instrumenty prawne, wprowadzane do ustawodawstwa wspólnotowego od lat osiemdziesiątych ${ }^{25}$. Wtedy to po raz pierwszy statuowano zasady dotyczące prowadzenia produkcji rolnej uwzględniającej potrzeby ochrony poszczególnych elementów środowiska. Przykładem mogą być postanowienia dyrektywy 91/414 dotyczącej obrotu środkami ochrony roślin ${ }^{26}$. W preambule tego aktu wskazano, że do realizacji celu, jakim jest poprawa produkcji roślinnej, nie należy dążyć kosztem ochrony zdrowia ludzi i środowiska. Z tego też względu przepisy proceduralne dopuszczające środki do obrotu powinny zapewniać wysoki stopień ochrony, a w szczególności muszą zapobiegać wprowadzeniu substancji stwarzających zagrożenie dla zdrowia ludzi i środowiska. Ponadto na mocy przepisów art. 2

Wyrok SPI z 21 października 2003 r., T-392/02, Solvay Pharmaceuticals BV v. Rada UE, ECR 2003, s. 2. Wyrok SPI z 11 lipca 2007 r., T-229/04, Królestwo Szwecji v. Komisja WE, ECR 2007. Wyrok SPI z 11 września 2002 r., T-13/99, Pfizer Animal Health v. Rada UE, ECR 2002, s. II, 3305.

Były to m.in. dyrektywa Rady 86/278/EWG z 12 czerwca 1986 r. w sprawie ochrony środowiska, a szczególnie gleby, przy stosowaniu osadów ściekowych w rolnictwie, O.J. L 181, p.6 i dyrektywa Rady 91/676/EWG z 12 grudnia $1991 \mathrm{r}$. dotycząca ochrony wód przed zanieczyszczeniem powodowanym przez azotany pochodzące ze źródeł rolniczych, O.J. L 375, p. 1 oraz rozporzadzenie Rady 2078/92/EWG z 30 czerwca 1992 r. dotyczace metod produkcji zgodnej z wymogami ochrony środowiska i zachowania krajobrazu, O.J. L 215, p. 85 ze zm.

Dyrektywa Rady 91/414/EWG z 15 lipca 1991 r., dotycząca wprowadzenia do obrotu środków ochrony roślin, O.J. L 91 , p. 230.1 , ze zm. 
pkt 13, art. 3 ust. 3 i art. 4 ust. 1 lit. b dyrektywy, w każdym przypadku, gdy jest to możliwe, środki ochrony roślin muszą być stosowane zgodnie z zasadą zintegrowanej ochrony. Oznacza to wymóg racjonalnego stosowania wszystkich dostępnych metod ochrony, tak aby środki chemiczne ograniczyć do minimum, a wprowadzać tylko wtedy, gdyby ich pominięcie prowadziłoby do gospodarczo niedopuszczalnych strat. Poza tym substancja może być umieszczona w wykazie tylko pod warunkiem, że w świetle obecnego stanu wiedzy nie ma szkodliwego wpływu na bezpieczeństwo ludzi, zwierząt i środowiska.

W konsekwencji implementacja tych unormowań do krajowych systemów prawnych przyczyniła się do ujednolicenia regulacji prawnych. Jednakże należy podkreślić, że normy zawarte w art. 6 i 174 TWE, mimo niezaprzeczalnej funkcji konsolidacyjnej, pozostawiają także aktywną rolę państwom członkowskim. Rola ta uwidacznia się poprzez przekazanie wielu kompetencji komitetom, składającym się z przedstawicieli poszczególnych państw oraz możliwość zastosowania odstępstw ze względu na regionalne zróżnicowanie. Potwierdzeniem tej tezy może być postanowienie art. 6 dyrektywy 91/414. Na mocy tego przepisu Stałemu Komitetowi do spraw Zdrowia Roślin ${ }^{27}$ powierza się podejmowanie decyzji w wielu kluczowych dla danej regulacji kwestiach, m.in. w sprawie dopuszczenia określonej substancji chemicznej oraz usunięcia substancji z listy środków dopuszczonych, jeśli w świetle aktualnego stanu wiedzy nie spełnia już wymagań bezpieczeństwa dla zdrowia ludzi, zwierząt i środowiska.

Ponadto zgodnie z przepisem art. 174 ust. 2 TWE, wykonanie założeń wysokiego poziomu ochrony środowiska uwzględniać powinno różnorodność sytuacji w poszczególnych regionach Wspólnoty. Przejawem realizacji tego postanowienia w ustawodawstwie rolnym są m.in. określone w przepisach dyrektywy 91/414 zasady dopuszczenia środka ochrony roślin, uwzględniające warunki rolnicze i środowiskowe, istotne dla stosowania omawianych produktów. Zgodnie z art. 10 ust. $3 \mathrm{i}$ art. 11, w przypadku stwierdzenia istotnych regionalnych odmienności rolnośrodowiskowych, biorąc pod uwagę poważne aspekty dotyczące zagrożenia ekologicznego, mogącego powstać przez stosowanie środka, państwo członkowskie może w danym regionie swojego terytorium m.in. 1) określić szczególne warunki stosowania środka ochrony roślin lub 2) odmówić wydania zezwolenia na dopuszczenie środka do obrotu, 3) tymczasowo ograniczyć jego stosowanie.

Na mocy wskazanej dyrektywy, istnienie wspólnotowych rozwiązań prawnych w tym zakresie nie oznacza utraty możliwości wprowadzenia przez państwo członkowskie odmienności regulacji, poprzez wprowadzenie bardziej obostrzonych zasad ochrony, ze względu na naturalnie uwarunkowania poszczególnych regionów rolniczych, ich zróżnicowanie środowiskowe. $\mathrm{Z}$ tego punktu widzenia przyjęte rozwią- 
zanie może być oceniane pozytywnie jako przejaw realizacji zasady regionalizacji we wspólnotowym ustawodawstwie rolnym, uwzględnianie różnic strukturalnych i przyrodniczych pomiędzy regionami rolniczymi, zgodnie z postanowieniami art. 33 ust. 2 oraz 174 ust. 2 TWE.

Z początkiem obecnej dekady ustawodawca europejski, dążąc do optymalizacji urzeczywistnienia kilku fundamentalnych zasad wspólnotowego prawa - zasady swobodnego przepływu towarów, zapewnienia jednakowych warunków konkurencji, wysokiego poziomu ochrony konsumentów i środowiska naturalnego - rozpoczął proces unifikacji regulacji prawnej dotyczącej środków ochrony roślin. Prawnym wyrazem tych założeń było wprowadzenie do systemu prawa rozporządzenia 396/2005, określającego dopuszczalne poziomy pozostałości pestycydów w żywności ${ }^{28}$, w którym jednolicie dla całej Wspólnoty określone zostały maksymalne poziomy pozostałości tych substancji w produktach rolnych. Państwa członkowskie utraciły odtąd uprawnienie, przysługujące im na mocy art. 3 ust. 2 dyrektywy 76/895/EWG ${ }^{29}$, do wprowadzenia na swoim terytorium, choćby czasowo, wyższych poziomów pozostałości tych substancji niż dopuszczalne na poziomie Wspólnoty. Natomiast pozostawiono możliwość wprowadzania przez poszczególne państwa na ich terytorium bardziej rygorystycznych norm niż europejskie standardy. Oznacza to, że regionalizacja oddziaływania nie może stać się uzasadnieniem do stosowania nawet temporalnych odstępstw od norm służących bezpieczeństwu żywości i ochronie środowiska.

Dalszym krokiem w celu unifikacji regulacji prawnej w tym zakresie będą projektowane przez organy Wspólnot zmiany ${ }^{30}$, co do zasady, mające służyć zmniejszeniu zagrożeń dla konsumentów i środowiska przez ograniczenie do minimum lub wyeliminowanie negatywnego oddziaływania pestycydów, a także wspieranie stosowania środków alternatywnych. Celem projektodawców jest unifikacja regulacji ze względu na potrzebę zapewnienia jednolitego poziomu ochrony zdrowia ludzi i środowiska w WE.

Jak wskazał ETS, ustawodawca wspólnotowy, dążąc do realizacji celów określonych w art. 33 TWE, jeśli jest to uzasadnione aktualnymi potrzebami społecznogospodarczymi, ma prawo takiego doboru instrumentów prawnych, poprzez które

Rozporządzenie Parlamentu i Rady 396/2005/WE z 23 lutego 2005 r. w sprawie najwyższych dopuszczalnych poziomów pozostałości pestycydów w żywności i paszy pochodzenia roślinnego i zwierzęcego oraz na ich powierzchni, O.J. L 70, p. 1. Aktem tym uchylono dyrektywę 76/895/EWG z 23 listopada 1976 r. odnosząca się do ustalania najwyższych dopuszczalnych poziomów pozostałości pestycydów w owocach i warzywach oraz na ich powierzchni, O.J. L 340, p. 26 i dyrektywę 90/642 z 27 listopada 1990 r. w sprawie ustalania najwyższych dopuszczalnych poziomów pozostałości pestycydów w niektórych produktach pochodzenia roślinnego, w tym owocach i warzywach oraz na ich powierzchni O.J. L 350 z p. 71, ze zm. 
może nadawać niektórym z celów czasowy priorytet. ${ }^{31} \mathrm{~W}$ ustawodawstwie rolnym od kilkudziesięciu lat obserwuje się wyraźne preferencyjne podejście do zapewnienia bezpieczeństwa jakości produktów rolnych, ochrony środowiska, a co za tym idzie - zdrowia publicznego konsumentów. Z tego też względu ustawodawca wykorzystuje rozporządzenia jako podstawowy instrument unifikacji prawa na obszarze Wspólnoty, ujednolicając zróżnicowaną dotąd w poszczególnych krajach UE regulację. Przyjęcie wskazanych jednolitych zasad ochrony pozwoli na wyważenie konfliktu kilku interesów: z jednej strony potrzeby zapewnienia swobodnego przepływu towarów i jednakowych warunków konkurencji w UE, z drugiej zaś wysokiego poziomu ochrony konsumentów i środowiska. Unifikacja regulacji na terenie UE nie oznacza jednak utraty możliwości aktywnego oddziaływania na kształt przyjmowanych regulacji przez państwa członkowskie, szczególnie poprzez prawo wprowadzenia odmienności rozwiązań ze względu na regionalne, ekologiczne aspekty na ich terytorium.

\section{Instrumenty ochrony środowiska w polskim ustawodawstwie rolnym}

Podobnie w ustawodawstwie polskim obserwuje się bardzo szybki rozwój regulacji dotyczącej ochrony środowiska w rolnictwie, co uwidoczniło się poprzez wprowadzenie wielu nowych instrumentów prawnych, których zasadniczym celem była poprawa efektywności gospodarowania w rolnictwie, ale dokonywana z zapewnieniem ochrony zdrowia ludzi, dobrostanu zwierząt i ochroną środowiska. Już w pierwszych latach transformacji ustrojowej, pomimo braku podstaw prawnych, prawo wspólnotowe stanowiło inspirację dla wprowadzanych do prawa rolnego unormowań w tym zakresie. Na mocy zawartej we wrześniu 1989 r. umowy międzynarodowej z EWG ${ }^{32}$ podjęto obok postanowień nawiązania współpracy gospodarczej w zakresie rolnictwa, również zobowiązania dotyczące ochrony środowiska. Świadomość istnienia tych zobowiązań oraz polityczne założenia przyszłego stowarzyszenia z EWG, spowodowały rozpoczęcie pierwszych, choć jeszcze bardzo nikłych starań o sprostanie wspólnotowym wymogom w zakresie ochrony środowiska w rolnictwie. ${ }^{33}$ Normatywną podstawą zapoczątkowanego procesu dostosowania naszego prawa był art. 68 Układu. ${ }^{34}$ Rolnictwo nie było wymienione wśród wska-

ETS w wyroku z 24.10.1973 r. w sprawie 5/73 Balkan-Import-Export GmbH v. Hauptzollamt Berlin-Packhof, ECR 1973, s. 7, s. 01091 czy w wyroku z 14.07.1994. w sprawie C-353/92., Republika Grecka v. Rada Unii Europejskiej, ECR 1992, I-03411.

Art. 12 ust. 1 i 2, art. 18 ust. 2 umowy międzynarodowej z 19 września 1989 r. między PRL a EWG w sprawie handlu oraz współpracy handlowej i gospodarczej, Dz.U. z 1990 r. Nr 38, poz. 214.

33 M.in. rozporządzenie MRiGŻ z 10 stycznia 1991 r. w sprawie bezpieczeństwa i higieny pracy przy stosowaniu i magazynowaniu środków ochrony roślin oraz nawozów mineralnych i sztucznych w rolnictwie, Dz.U. Nr 14, poz. 64, które z zastapiło obowiazujacy dotad akt z 1959 r. leniu tempa, jak i priorytetów harmonizacji, co miało początkowo wpływ na wymiar prac legislacyjnych, por. Komentarz do Układu Europejskiego ustanawiającego stowarzyszenie między RP z jednej strony a WE i państwa- 
zanych w art. 69 strategicznych dziedzin poddanych harmonizacji, jednakże przepis ten wskazywał, jako mające szczególne znaczenie, regulacje dotyczące ochrony zdrowia ludzi, zwierząt, roślin, środowiska naturalnego oraz przepisy techniczne dotyczące także rolnictwa. Zauważono wyraźnie potrzebę działań w celu zwiększenia efektywności w rolnictwie (art. 77 ust. 1), lecz jako zadanie priorytetowe wskazano „rozwijanie i umacnianie współpracy w tak ważnej dziedzinie, jaką jest walka z pogarszającym się stanem środowiska naturalnego", a szczególny nacisk został położony na oddziaływanie rolnictwa na środowisko naturalne (art. 80 ust. 1-3).

Postanowienia Układu stały się podstawą harmonizowania rozwiązań prawnych w zakresie środków ochrony roślin w ustawie z 1995 r. o ochronie roślin uprawnych $^{35}$. W akcie tym podjęto próbę zbliżenia regulacji prawnej do norm ustanowionych w przepisach WE poprzez wprowadzenie instrumentów zapobiegających skażeniu środowiska w wyniku stosowania środków ochrony roślin, m.in. 1) zasadę uwzględniania w pierwszej kolejności metod ochrony, pozwalających ograniczyć stosowanie środków chemicznych do minimum, 2) obowiązek ścisłego stosowania zaleceń użycia środków, aby nie dopuścić do skażenia środowiska, 3) instrumenty kontrolne organów Inspekcji Ochrony Roślin, m.in. wstęp na grunty, pobieranie próbek gleby, roślin i środków ochrony roślin, kontrola dokumentacji.

Jednocześnie, należy zauważyć wpływ przyjętego zobowiązania harmonizacji regulacji prawnej w zakresie przeciwdziałania zagrożeniom powodowanym przez rolnictwo w środowisku na kształt instrumentów prawnych, od wielu lat obowiązujących w ustawodawstwie polskim. Przykładowo w ustawie z 1995 r. o ochronie gruntów rolnych i leśnych ${ }^{36}$ ustawodawca po raz pierwszy wskazał na wadliwą działalność rolniczą jako jedną z przyczyn degradacji i dewastacji gruntów (art. 4 pkt 16, 17). Równocześnie, jak wynikało z pierwotnej treści art. 15 ust. 1 i 5, degradacja gruntów mogła wystąpić na skutek nieprzestrzegania zasad stosowania środków ochrony roślin. W obecnym brzmieniu tego przepisu nie wymienia się już expressis verbis nieprawidłowego używania środków ochrony roślin jako przyczyny degradacji. Uzasadnieniem tego, jak należy przypuszczać, jest zauważenie, iż degradacja gruntów może powstać na skutek wadliwej działalności rolniczej, a więc nie tylko poprzez szkodliwe używanie środków ochrony roślin, lecz także nieprzestrzeganie zasad stosowania i przechowywania nawozów czy wadliwe rolnicze wykorzystanie na terenie gospodarstwa osadów ściekowych. To uzasadnia stwierdzenie,

mi członkowskimi z drugiej strony, red. C. Banasiński, J.A. Wojciechowski, Biblioteka Europejska, URM, Biuro Integracji Europejskiej oraz Pomocy Zagranicznej 1994, s. 195 czy Z. Brodecki, E. Gromnicka, Układ Europejski z komentarzem, Warszawa 2002, s. 113 oraz A. Lichorowicz, Ocena stopnia harmonizacji polskiego prawa z prawem Unii Europejskiej, BSE Kancelaria Sejmu 1998, z. 1, s. 10. kresie było nieprzypadkowe i odpowiadało postulatom doktryny. Por. A. Lichorowicz, Stowarzyszenie Polski..., s. 51 i 57. Ustawa z 3 lutego 1995 r. o ochronie gruntów rolnych i leśnych, Dz.U. Nr 16, poz. 78. 
o uwzględnieniu przez ustawodawcę szerszego kontekstu ochronnego w omawianej regulacji.

Potwierdzeniem tej tezy jest też obowiązek przeciwdziałania degradacji nałożony na właścicieli gruntów, a razie jej wystąpienia, możliwość wprowadzenia na drodze administracyjnej nakazu dokonania odpowiednich zabiegów lub zlecenia wykonania zastępczego na koszt właściciela, ale z możliwością wykorzystania do czasu zwrotu kosztów środków Funduszu Ochrony Gruntów Rolnych (art. 15 ust. 5). Ustawodawca dał tym samym wyraz dbałości nie tylko o produkcyjne funkcje gruntów rolnych, jak to miało miejsce dotychczas, ale również o ich funkcje ekologiczne.

Założenie rolnictwa zrównoważonego, spełniające zarówno funkcję produkcyjną, ochrony dochodowości, jak i ekologiczną, wspiera także regulacja w zakresie płatności bezpośrednich do gruntów rolnych.

\section{Instrumenty wsparcia bezpośredniego w ustawodawstwie rolnym}

Płatności bezpośrednie do gruntów rolnych pojawiły się w ustawodawstwie wspólnotowym w 1992 r. jako środki pomocy wyrównawczej, rekompensującej producentom rolnym spadek poziomu cen gwarantowanych. ${ }^{37}$ System ten, w założeniach reformy MacSharry'ego, miał spełniać dwie podstawowe funkcje: 1) redukcyjną - dopłaty miały początkowo charakter środka służącego obniżeniu skali strukturalnej nadprodukcji oraz 2) rekompensacyjną - dopłaty wraz z premią za wyłączenie gruntów, przeciwdziałać miały skutkom obniżenia dochodów producentów rolnych spowodowanych redukcją poziomu cen gwarantowanych. Jednakże analiza regulacji prawnej w tym zakresie pozwala w przyjętych rozwiązaniach prawnych zauważyć realizację zarówno zasady regionalizacji oddziaływania, jak i ochrony środowiska. W przepisach rozporządzenia 1765/92 areał gruntów podlegający płatnościom, jak i kwota płatności były regionalnie zróżnicowane. Dopłata przyznawana była na powierzchnię gruntów przeznaczaną na uprawę, nieprzekraczającą średniej powierzchni regionalnej, a wysokość dopłaty uwzględniała wydajność produkcji w danym regionie. Podstawą wyliczenia płatności był plan regionalizacji opracowywany dla poszczególnych regionów przez państwa członkowskie, przedstawiany do zatwierdzenia Komisji (art. 2 i 3). Pomimo zunifikowanego systemu płatności na terenie UE, przyjęty kształt regulacji pozwalał na zróżnicowanie instrumentów i lepsze dostosowanie do potrzeb poszczególnych regionów.

37 Instrumenty te wprowadzano odrębnie na kilku rynkach rolnych m.in. w przepisach rozporządzenia Rady $1765 / 92$ z 30 czerwca 1992 r. ustanawiającego system wsparcia producentów rolnych niektórych roślin uprawnych, O.J. L 181, p.12. Szerzej J. A. McMahon, Law of the Common Agricultural Policy, Harlow 2000, s. 43-44 oraz E. Tomkiewicz, Geneza i funkcje rolniczych dopłat bezpośrednich w ustawodawstwie wspólnotowym, (w:) Problemy prawa rolnego i ochrony środowiska, Księga pamiątkowa Prof. W. Pawlaka, Poznań 2004, s. 235 i n. 
System dopłat kompensacyjnych został uzupełniony przez środki współtowarzyszące, a podstawowym instrumentem było wyłączenie gruntów rolnych z produkcji. Producenci ubiegający się o płatność zobowiązani byli do odłogowania regionalnie zróżnicowanej części gruntów swego gospodarstwa w zamian za rekompensatę, jednakże obowiązek ten nie dotyczył początkowo małych gospodarstw rolnych, $\mathrm{z}$ uwagi na ochronę ich dochodowości. Ponadto ustawodawca powiązał system płatności z ekstensyfikacją produkcji i przyznaniem środków pomocy zachęcających do ochrony środowiska, krajobrazu, ale początkowo przesłanki ekologiczne nie miały zasadniczego znaczenia. Instytucja wyłączenia gruntów rolnych z produkcji, mimo jej niezaprzeczalnego wpływu na stan środowiska, nie była w pierwszym okresie tak ściśle powiązana z obowiązkami na rzecz jego ochrony. W rozporządzeniu wykonawczym Komisji 2293/92 ${ }^{38}$ wprowadzono możliwość wieloletniego wyłączenia terenów o szczególnie istotnych walorach naturalnych oraz uprawniono państwa członkowskie do określenia obowiązkowych zabiegów pielęgnacyjnych na odłogowanych gruntach. Jednakże, zgodnie z treścią art. 3, nawet w przypadku prawnego uregulowania tych obowiązków na terenie danego państwa, ich niewypełnienie nie oznaczało utraty płatności kompensacyjnej, a jedynie obniżenie premii z tytułu wyłączenia. Trzeba w tym miejscu nadmienić, że usprawiedliwieniem takiego kształtu przyjętej regulacji było równoczesne wprowadzenie rozporządzenia Rady 2078/92 $2^{39}$, przewidującego cały szereg obowiązków nakładanych na producentów, do których stosowania stymulowały bodźce finansowo-prawne.

Różnica między regulacją prawną z 1992 r. a obowiązującym obecnie w tym zakresie rozporządzeniem Rady $\mathrm{nr} 1782 / 2003^{40}$ jest zasadnicza. Po pierwsze dlatego, że płatności zostały uniezależnione od wielkości i rodzaju produkcji - zasada decoupling. Skrajnym przejawem realizacji tej zasady jest przyznanie płatności do gruntów, które zostały z tej produkcji wyłączone (art. 53, 54). Po drugie, uzależniono przyznanie pomocy od utrzymania gruntów w dobrej kulturze rolnej, zgodnie z wymogami ochrony środowiska - zasada cross-compliance (art. 3). Spełnienie wymagań określanych jako standardy dobrych praktyk rolniczych oraz wymagań w zakresie ochrony środowiska staje się odtąd conditio iuris przyznania płatności. Wypełnienie tych ,warunków środowiskowych" ${ }^{41}$ ma z założenia, obok funkcji ekologicznej, stanowić także społeczne uzasadnienie dla powszechnego wspierania posiadaczy gruntów rolnych za pośrednictwem wspólnotowych środków publicznych. Konsekwencją przyjęcia takiego założenia jest przyznanie wsparcia finanso-

Rozporządzenie Komisji WE nr 2293/92 z 31 lipca 1992 r. w sprawie wykonania przepisów rozporządzenia Rady nr 1765/92, O.J. L 221, p. 19.

Rozporządzenie Rady WE nr 2078/92 z 30 czerwca 1992 r. o metodach produkcji rolnej zgodnej z wymogami ochrony środowiska i ochrony krajobrazu, O.J. L 215, p. 85.

Rozporządzenie Rady WE nr 1782/2003 z 29 września 2003 r. ustanawiające wspólne systemy wsparcia bezpośredniego w ramach wspólnej polityki rolnej i ustanawiające określone systemy wsparcia dla rolników oraz zmieniające inne rozporządzenia, O.J. L 270, p.1.

Takiego określenia używa G. Bivona, op. cit., s. 53. 
wego niejako „w zamian” za wysoką jakość produktów rolnych oraz dokonywanie określonych zabiegów agrośrodowiskowych. Tezę tę potwierdza definicja pojęcia „działalność rolnicza” - zgodnie z art. 2 lit. c - oznacza „produkcję, hodowlę lub uprawę produktów rolnych (...) lub utrzymywanie gruntów w dobrej kulturze rolnej zgodnej z ochroną środowiska". Dlatego w systemie europejskiego wsparcia bezpośredniego utrzymanie gruntów w dobrej kulturze rolnej, zgodnej z ochroną środowiska zostało uznane za równoważne innym formom działalności rolniczej, co dotyczy zwłaszcza sytuacji przyznania płatności do gruntów wyłączonych z produkcji. W konsekwencji nieprzestrzeganie tych wymagań wiąże się ze zmniejszeniem lub całkowitą redukcją płatności (art. 6 i 7). Kontrola przestrzegania zasad crosscompliance przez rolników pozostawiona została państwom członkowskim, które w przepisach krajowych określają zasady i tryb przeprowadzania kontroli (art. 25). Od efektywności tej kontroli zależy skuteczność tego instrumentu.

Ponadto wyszczególnienie wymogów ochrony środowiska w załączniku nr III do rozporządzenia 1782/2003 jest także wyrazem potrzeby istnienia zunifikowanej regulacji prawnośrodowiskowej w tym zakresie na szczeblu wspólnotowym. Inaczej ustawodawca europejski podchodzi do wymagań w zakresie zasad dobrej praktyki rolniczej. Na mocy art. 5 rozporządzenia, państwa członkowskie mają zapewnić, by wszystkie grunty rolne, a w szczególności te, które nie są już wykorzystywane do celów produkcyjnych, były utrzymywane w dobrej kulturze rolnej, zgodnej z ochroną środowiska. Dlatego uprawnieniem poszczególnych państw stało się normatywne określenie tych wymagań przy uwzględnieniu m.in. warunków glebowych, klimatycznych, istniejącego systemu gospodarowania, metod upraw i struktury gospodarstw rolnych oraz w oparciu o minimalne wymogi w zakresie dobrej kultury rolnej, określone w załączniku nr IV rozporządzenia. Przykładowo w polskich przepisach ${ }^{42}$ wskazano wymogi wchodzące w zakres dobrej praktyki rolniczej, m.in. zasady służące zachowaniu tradycyjnych cech ukształtowania powierzchni terenu i krajobrazu wsi.

Przyjęte rozwiązanie świadczy o wyróżnieniu przez ustawodawcę europejskiego zasadności regionalnego zróżnicowania prawnych instrumentów oddziaływania także w zakresie płatności w ramach wsparcia bezpośredniego. Ponadto stanowi to wyraz powiązania realizacji celów polityki rynkowej z innymi podejmowanymi w ramach WPR założeniami: ochroną zdrowia publicznego, zapewnieniem odpowiedniej jakości żywności, dobrostanu zwierząt i ochroną środowiska. $\mathrm{Z}$ uwagi na to regulacja ta wymaga zunifikowanych form oddziaływania, ale $\mathrm{z}$ uwzględnieniem regionalnych zróżnicowań. 


\section{Instrumenty regionalizacji oddziaływania w ustawodawstwie rolnym}

Przejawem europeizacji prawa rolnego wskazywanym w niniejszym opracowaniu jest realizacja zasady regionalizacji oddziaływania ustawodawcy europejskiego. Zgodnie $\mathrm{z}$ jej założeniami, wprowadzane instrumenty prawne uwzględniać muszą zróżnicowanie terenów rolniczych, specyfikę warunków naturalnych obszarów, na które mają oddziaływać. Podstawy normatywne w tym zakresie stworzył art. 33 ust. 2 TWE, wskazując, by przy kształtowaniu WPR i doborze instrumentów ją realizujących uwzględniać różnice strukturalne i przyrodnicze pomiędzy poszczególnymi regionami rolniczymi. Niewspółmierność rozwoju struktur rolnych i zróżnicowanie warunków naturalnych, występujące ze szczególnym nasileniem na terenach górskich oraz na obszarach określonych jako szczególnie trudne do prowadzenia działalności w rolnictwie, stały się przesłanką do wprowadzenia szczególnej regulacji prawnej, realizującej założenia regionalizacji we wspólnotowym ustawodawstwie rolnym. Mimo wyraźnych podstaw traktatowych, pierwsze działania w tym zakresie zostały podjęte poprzez wprowadzenie przepisów dyrektywy Rady $268 / 75^{43}$. Podstawową przesłanką wprowadzenia tej regulacji była potrzeba dostosowania założeń zapoczątkowanej w 1972 r. reformy strukturalnej do obszarów górskich i innych obszarów o niekorzystnych warunkach geoklimatycznych, ekonomicznych i społecznych. Poprzez wprowadzenie szeregu zróżnicowanych instrumentów prawnych ustawodawca europejski dążył do realizacji kilku zakładanych celów: utrzymania godziwego dochodu rolników, zapewnienia ciągłości zachowania terenów wiejskich, przeciwdziałania ich depopulacji oraz podejmowania działań na rzecz ochrony środowiska ekologicznie cennych obszarów. Jak słusznie podkreśla A. Lichorowicz, przywrócenie rolniczego charakteru omawianych regionów służyć miało nie tyle ochronie produktywności rolnej, lecz ochronie środowiska naturalnego tych terenów, poprzez obowiązek dokonywania podstawowych zabiegów agrotechnicznych ${ }^{44}$. Potwierdzeniem tej tezy są postanowienia szczególne dyrektywy. Wsparcie dla młodych rolników i zobowiązanie do pięcioletniego prowadzenia działalności w zamian za dopłaty kompensacyjne (art. 6 dyrektywy) miało przeciwdziałać depopulacji terenów o trudnych warunkach do prowadzenia działalności w rolnictwie, ale również przyczyniało się do zrekompensowania niższych dochodów związanych z utrudnieniami w produkcji. Dodatkowe preferencje dla podejmujących działalność rolniczą na tych obszarach wynikały również ze zwolnienia od obowiązku spełniania wymogów przewidzianych w ogólnych przepisach strukturalnych dla gospodarstw rozwojowych w zakresie uzyskania odpowiedniej dochodowości, kwalifikacji, biznesplanu (art. 10 dyrektywy). Na tych terenach istotą stało się samo 
utrzymanie produkcji rolnej, efektywność gospodarowania w rolnictwie była drugoplanowa. Kolejne akty prawne realizujące założenia $\mathrm{WPR}^{45}$, z pewnymi modyfikacjami, utrzymały główne kierunki wspólnotowego wsparcia dla tych regionów.

Tymczasem w ustawodawstwie polskim w okresie transformacji ustrojowej ustawodawca z jednej strony widział potrzebę działań prawnych na rzecz postulowanej w doktrynie modernizacji rolnictwa ${ }^{46}$, lecz z drugiej strony odstępował od wprowadzonych w latach osiemdziesiątych regulacji, które można było uznać za przejaw recepcji rozwiązań europejskich ${ }^{47}$, wspierających rozwój infrastruktury, dostosowujących strukturę produkcji rolniczej do warunków przyrodniczych, rozwój agroturystyki. Zadania w tym zakresie podjęto dopiero w 2001 r. w zawetowanej przez Prezydenta RP ustawie o rozwoju społeczno-gospodarczym regionów górskich ${ }^{48}$, która miała określać warunki i zasady wspomagania, aktywizacji i zrównoważonego rozwoju regionów górskich, dokonywane przy zachowaniu i ochronie środowiska naturalnego.

Obecnie założenia służące wspieraniu rolnictwa na terenach o utrudnionych warunkach gospodarowania realizowane są w ramach PROW 2007-2013 ${ }^{49}$. Podstawę prawną w tym zakresie stanowią przepisy rozporządzenia Rady 1698/2005 ${ }^{50}$ oraz polskiej ustawy z 2007 r. o wspieraniu rozwoju obszarów wiejskich ${ }^{51}$, jak również przepisy rozporządzenia MRiRW z 2007 r. w sprawie wspierania gospodarowania na obszarach górskich i innych obszarach o niekorzystnych warunkach gospodarowania $^{52}$. Zasadnicze warunki uzyskania pomocy dla tych regionów nie uległy na przestrzeni kilkudziesięciu lat zasadniczym zmianom. Dodatkowa płatność jest przyznawana rolnikowi prowadzącemu gospodarstwo rolne na obszarach zaliczonych do obszarów ONW, który zobowiąże się do prowadzenia działalności rolni-

M.in. rozporządzenie Rady 797/85, O.J. L 93, p. 1, rozporządzenie Rady 2328/91, O.J. L 218, p.1 i rozporządzenie Rady 2081/93, O.J. L 193, p. 5. a następnie przepisy rozporządzenia 1257/99, O.J. L 160, p. 80, które normowały zasady wsparcia regionów o mniej korzystnych warunkach do prowadzenia produkcji rolnej, w tym również regionów górskich (art. 18).

46 Por. zwłaszcza §1 rozporządzenia MRiGŻ z 6 lipca 1991 r. w sprawie zasad realizacji wydatków budżetowych na finansowanie rozwoju rolnictwa w 1991 r., Dz.U. Nr 65, poz. 284, gdzie przeznaczono środki finansowe na modernizację gospodarstw rolnych czy inwestycje na terenach wiejskich.

47 Przykładowo w 1991 r. uchylono podstawę funkcjonowania Funduszu Socjalnego Wsi (ustawa z 24 lutego 1989 r., Dz.U. Nr 10, poz. 54 ze zm.), którego środki przeznaczane były na podnoszenie poziomu życia ludności na terenach wiejskich, także podstawę wspierania rolnictwa prowadzonego na terenach górskich, którą stanowiła uchwała RM z 1985 r. o w sprawie aktywizacji gospodarczej i społecznej oraz rozwoju rolnictwa na terenach górskich i górzystych, M.P. Nr 2, poz. 11. Szerzej M.A. Król, Środki prawne regionalizacji w ustawodawstwie rolnym, „Studia luridica Agraria” 2002, t. 2, s. 220.

48 Tekst ustawy w materiałach sejmowych na: http://ks.sejm.gov.pl:8009/proc3/ustawy/2323_u.htm. t

49 Program zatwierdzony decyzją Komisji WE z 7 września 2007 r., CCl 2007PL06RPO001.

50 Art. 36 lit. a ppkt i) oraz ii) oraz art. 37 rozporządzenia Rady WE nr 1698/2005 z 20 września 2005 r. w sprawie wspierania rozwoju obszarów wiejskich przez Europejski Fundusz Rolny na rzecz rozwoju Obszarów Wiejskich, O.J. L 277, p.1. ze zm.

51 Art. 5 ust. 1. pkt 12 ustawy z 7 marca 2007 r. o wspieraniu rozwoju obszarów wiejskich z udziałem środków Europejskiego Funduszu Rolnego na rzecz rozwoju Obszarów Wiejskich, Dz.U. Nr 64, poz. 427 ze zm. cy finansowej w ramach działania „Wspieranie gospodarowania na obszarach górskich i innych obszarach o niekorzystnych warunkach gospodarowania objętej PROW 2007-2013”, Dz.U. Nr 68, poz. 448 ze zm. 
czej przez co najmniej 5 lat. Nadal także conditio iuris przyznania płatności stanowi utrzymywanie gruntów w dobrej kulturze rolnej, zgodnej z ochroną środowiska (§ 2 pkt 1 i 2 rozp.). Istotnym novum wprowadzonym przez polskie rozporządzenie jest uzależnienie wysokości wsparcia od powierzchni gospodarstwa. W pełnej wysokości wsparcie przysługuje gospodarstwom do 50 ha, za nadwyżkę tej powierzchni stosuje się stawkę degresywną, z wyłączeniem wsparcia działek powyżej 300 ha ( 2 pkt 3 i $\S 3$ ust. 3 rozp.). Poprzez takie ukształtowanie zasad przyznania płatności ustawodawca polski realizuje kolejne założenie polityki rolnej - wsparcie dochodów mniejszych gospodarstw o charakterze rodzinnym, prowadzonych na terenach, gdzie występują dodatkowe utrudniania w produkcji. Przyjęcie degresywności powoduje, jak należy przypuszczać, przesunięcie akcentu funkcji tej pomocy - obok ekologicznej i demograficznej, ustawodawca podkreśla w większym zakresie potrzebę wspierania dochodów mniejszych i z powodów utrudnień w produkcji, mniej efektywnych gospodarstw. Osłabieniu uległa natomiast funkcja rekompensacyjna tego środka.

Konkludując, regionalizacja we wspólnotowym ustawodawstwie rolnym nie jest celem samym w sobie. Realizujący ją zespół instrumentów prawnych musi służyć potrzebie zindywidualizowanego podejścia ustawodawcy do części terytorium Wspólnoty ze względu na konieczność ochrony na danym obszarze szczególnych wartości, czasami służy przesunięciu akcentu na rzecz jednego z realizowanych w ramach WPR celów.

\section{Wsparcie priorytetowych założeń polityki rolnej}

Na zakończenie rozważań trzeba odnotować wpływ prawa wspólnotowego na kształt przyjmowanych w naszym kraju rozwiązań prawnych w prawie rolnym. W zakresie przedstawianych w niniejszym opracowaniu zagadnień można wskazać m.in. nowe kierunki działań Agencji Restrukturyzacji i Modernizacji Rolnictwa ${ }^{53}$, określone w art. 4 ustawy, a uszczegółowione w przepisach rozporządzenia $\mathrm{RM}^{54}$. Ustalenie szczegółowego zakresu i kierunków działań w ramach przyznanych zadań oraz sposobów ich realizacji odbywa się z uwzględnieniem priorytetów polityki państwa w zakresie rolnictwa, rozwoju wsi i rynków rolnych (art. 4 ust. 6 ustawy). Wśród celów, na które przeznaczana ma być pomoc finansowa, obok poprawy struktury agrarnej, efektywności produkcji, poprawy jakości produktów rolnych, wymieniono utrzymanie lub poprawę wymagań w zakresie ochrony środowiska ( $\$ 2$ ust. 2). Ponadto należy zauważyć, że inwestycje realizowane w gospodarstwach rolnych lub działania, podejmowane w celu wznowienia produkcji po wystąpieniu klęski żywiołowej, mogą korzystać ze zwiększonej wysokości udzielanej pomocy finanso- 
wej, jeśli są prowadzone na terenach górskich, terenach o niekorzystnych warunkach gospodarowania, obszarach Natura 2000 ( 5 ust. 1 i $§ 10$ ust. 3 pkt 2). Należy podkreślić, że sprostanie wymaganiom z zakresu ochrony środowiska, a przez to poprawa jakości produktów rolnych, jak również potrzeba wsparcia rolnictwa prowadzonego na obszarach o utrudnieniach dla działalności rolniczej, staje się obecnie pod wpływem regulacji europejskiej jednym z priorytetów polityki rolnej państwa, korzystającym z przyznanej pomocy, co znajduje odzwierciedlenie w obowiązujących regulacjach.

\section{Wnioski}

Przeprowadzone rozważania pozwalają na postawienie kilku wniosków. We współczesnym wspólnotowym prawie rolnym w coraz większym zakresie podejmowane zostaje traktatowe zobowiązanie do uwzględniania w przyjmowanych rozwiązaniach obowiązku zapewnienia wymogów ochrony środowiska. Od kilku lat wzgląd na potrzebę ochrony środowiska realizowany jest w ramach obydwu filarów tej polityki, zarówno w polityce rozwoju obszarów wiejskich, jak i w polityce rynkowej.

W polityce strukturalnej EWG wymogi ochrony środowiska stały się jednym z poważniejszych aspektów już w połowie lat siedemdziesiątych. Obecnie podkreśla się funkcje środowiskowe pełnione przez rolnictwo, a szczególnie uwypuklona została funkcja ekologiczna rolnictwa pełniona dla obszarów wiejskich. Utrzymanie działalności rolniczej stanowi często jedyną gwarancję zachowania wartości środowiskowych na danym obszarze. Oddziaływanie to widoczne jest zwłaszcza na terenach górskich i innych terenach o utrudnionych warunkach gospodarowania, które korzystają ze szczególnych form pomocy, uzależnionej od podejmowania określonych wymagań środowiskowych. Ponadto realizujący założenia WPR PROW 20072013 promuje zrównoważone formy rolnictwa, prowadzone na terenach o cennych walorach krajobrazowych, przewiduje liczne instrumenty wsparcia stanowiące zachętę do podejmowania działań sprzyjających ochronie środowiska (wymaganych przy modernizacji gospodarstw rolnych, pomocy dla młodych rolników).

Bezpośrednim przejawem realizacji zasady ochrony środowiska jest także włączenie warunków środowiskowych do instrumentów prawnych, tradycyjnie zaliczanych do I filaru WPR, czyli polityki rynkowej. Uzależnienie przyznania pomocy finansowej zarówno we wspólnotowym, jak i polskim akcie dotyczącym płatności do gruntów rolnych od przestrzegania zasad ochrony środowiska, jest wyrazem obserwowanej tendencji do uwzględniania wymagań środowiskowych we wszystkim segmentach polityki rolnej. Spełnienie ustanowionych zgodnie z tą zasadą reguł realizuje założenie bezpieczeństwa żywnościowego - produkcji żywności o odpowied- 
nich standardach jakościowych, jak i zapewnienia jakości środowiska. Takie rozwiązanie stanowi realizację założeń art. 6 TWE.

Europejski model rolnictwa oznacza podtrzymywanie rolnictwa we wszystkich regionach UE, w tym także regionach o trudnych warunkach do prowadzenia produkcji rolnej, silniejsze powiązanie z ochroną środowiska (m.in. rolnictwo ekologiczne, agroturystyka), ochroną krajobrazu i dziedzictwa kulturowego. Ustawodawca europejski promuje obecnie rolnictwo zrównoważone, godzące konieczność zapewnienia właściwego poziomu produkcji i dochodów producentom rolnym z potrzebami rozwoju obszarów wiejskich, ochroną krajobrazu. Oznacza to przyzwolenie na zrównoważone (tradycyjne i ekstensywne) formy gospodarowania na gruntach położonych na obszarach o niekorzystnych warunkach naturalnych po to, by zapewnić rolnicze użytkowanie ziemi, utrzymać żywotność obszarów wiejskich, przeciwdziałać pojawiającym się problemom demograficznym. Uwidocznienie potrzeby wsparcia dla rolnictwa na tych obszarach i prawne instrumenty tej pomocy w ustawodawstwie polskim można uznać jako przejaw europeizacji prawa rolnego.

Ochrona środowiska w rolnictwie, w ocenie ustawodawcy wspólnotowego, wymaga zunifikowanych form oddziaływania. Założenie unifikacji prawa rolnego nie oznacza jednak utraty wpływu poszczególnych państw na kształt regulacji prawnej w tym zakresie. ${ }^{55}$ Realizując założenie określone w art. 174 ust. 2 TWE, ustawodawca dopuszcza uprawnienie dla państw członkowskich do zróżnicowania regulacji prawnej. Na szczeblu wspólnotowym, poza oczywistym wpływem na kształtowanie WPR, jak i na proces tworzenia prawa artykułującego założenia tej polityki, trzeba odnotować wzrastające znaczenie stałych komitetów, składających się z przedstawicieli poszczególnych państw. W ramach ustanowionej procedury „komitologii”, w coraz szerszym zakresie uszczegółowiają one zadania określone w aktach ogólnych oraz wprowadzają temporalne odstępstwa od ustanowionych zasad, przez to mają realny wpływ na kształt przyjmowanej regulacji prawnej. Na szczeblu krajowym każde z państw, uwzględniając założenia WPR, opracowuje własną politykę rolną wobec rolnictwa i obszarów wiejskich, określa jej priorytety i dobiera instrumenty oddziaływania do zróżnicowanych warunków. Na organach państw członkowskich spoczywa obowiązek implementacji prawa wspólnotowego, m.in. zapewnienie bezwzględnie obowiązującemu prawu wspólnotowemu skuteczności, transpozycję postanowień dyrektyw, zapewnienie efektywności kontroli. Poszczególne państwa, mimo generalnej unifikacji rozwiązań prawnych w zakresie poddanym regulacji wspólnotowej odnoszącej się do ochrony środowiska, zachowały możliwość wprowadzenia odrębności ze względu na regionalne zróżnicowanie 
środowiskowe. Należy zatem postulować jak najlepsze wykorzystanie możliwości zróżnicowania tych instrumentów, dostosowując je do sytuacji polskich regionów.

Jak zostało odnotowane w niniejszym opracowaniu, pod wpływem regulacji wspólnotowej ochrona środowiska w rolnictwie i rolnictwo na terenach o utrudnionych warunkach gospodarowania korzystają z przyznanych form wsparcia jako uznane normatywnie priorytety polityki rolnej naszego państwa. Dlatego szczególnego znaczenia nabiera wyrażone na podstawie przedstawionych rozważań przekonanie o potrzebie dostosowania do wskazanych założeń także tej części regulacji normatywnej, która nie podlega instrumentom WPR. 


\section{Symptoms of europeisation in agricultural law}

\section{Summary}

The problem of europeisation of Polish law is nowadays one of the question undertaken in almost every scientific sphere, this phenomenon undeniably is concerned with agricultural law, as well. The purpose of the present paper is an attempt to review the influence of European law by analysis of certain legal solutions: instruments of environmental protection in agriculture achieved by legal rules of applying pesticides, instruments of support to farmers in mountains and other areas with natural handicap, and instruments of direct payments.

With regard to conducted analyses it is possible to find out new priorities of Common Agricultural Policy reflected in binding regulations. The development of European regulations in the field of environmental protection in agriculture reflects the Treaty of Rome principle to harmonious and balanced development of economic activities, sustainable growth respecting the environment. The analysis of presented regulations shows the tendency to regulate agri-environment questions uniformly on EU level but with regional differences in local regulations. The necessity of regionalization of legal instruments can't mean the possibility to even temporal exceptions to rules protecting human health, safety of food, and protection of environment.

The analysis of chosen instruments shows that European legislator decided to use regionalization instruments in direct payments shames. This confirms the thesis of straight connection of agri market policy purposes with other political principles : protection of public health, assurance of proper quality of food, animal welfare, and environmental protection. Considering above mentioned data this regulation requires uniform instruments but with respect for regional differentiation. As a result of the conducted analyses it has also been indicated that the assumptions of unification of agricultural law do not mean the loss of influence of individual countries on the shape of legal regulations. 